\title{
だしとうま味の食品化学
}

二宮くみ子

\section{Food Science of Dashi and Umami Taste}

\author{
Kumiko Ninomiya \\ Non-Profit Organization Umami Information Center; 8-7-1202 Niban-cho, Chiyoda-ku, Tokyo 102-0084, Japan.
}

(Received April 22, 2016)

\begin{abstract}
Umami is a basic tastes, along with sweet, salty, bitter and sour, which is imparted by glutamate, one of the free amino acids in foods. Since its discovery of umami by a Japanese scientist in 1908, umami is now perceived globally a basic taste. Recent collaboration among chefs and researchers on traditional soup stocks showed a difference in taste profiles of Japanese soup stock 'dashi' and Western style soup stock. The free amino acids profile's in dashi and soup stock showed how Japanese have traditionally adopted a simple umami taste. The exchange of knowledge on cooking methods and diverse types of umami rich foods in different countries displays the blending of the culinary arts, food science and technology for healthy and tasty solutions. Since Japanese cuisine 'WASHOKU' was listed in the 'Intangible Heritage of UNESCO' in 2013, many people in the world now have great interest in Japanese cuisine. One of the unique characteristics of this cuisine is that 'dashi' is an indispensable material for cooking a variety of Japanese dishes. Many chefs from Europe, US and South America have come to Japan to learn Japanese cuisine in the last 10 years, and umami has become recognized as a common taste worldwide. Researchers and culinary professionals have begun to pay attention to the traditional seasonings and condiments rich in glutamate available throughout the world.
\end{abstract}

Key words_ _ umami; dashi; amino acids; soup stock

\section{はじめに}

2013 年 12 月，「和食：日本人の伝統的な食文化」 がユネスコ（国際連合教育科学文化機関）無形文化 遺産に登録された。登録とは，「無形文化遺産保護 条約」の第 2 条にある定義に基づき無形文化遺産の 代表的な一覧表に記載されたことを意味している. この一覧表に記載されるためには，登録の対象と なった「和食」が「世代から世代へと伝承され」, 「自然との相互作用及び集団に対応して絶えず再現」 される必要がある。ささらに，和食の特徴として下記 の 4 点が挙げられている.

1. 多様で新鮮な食材とその持ち味

2. 栄養バランスに優れた健康的な食生活

3. 自然の美しさや季節の移ろいの表現

4. 正月などの年中行事との密接な関わり

NPO 法人うま味インフォメーションセンター（１020084 東京都千代田区二番町 8-7-1202)

e-mail: kumiko04221846@gmail.com

本総説は, 日本薬学会第 135 年会シンポジウムS63 で 発表した内容を中心に記述したものである。
「栄養バランスに優れた健康的な食生活」につい ては以下の解説が付されている。「一汁三菜を基本 とする日本の食事スタイルは理想的な栄養バランス と言われている。また，「うま味」を上手に使うこ とによって動物性脂肪の少ない食生活を実現してお り, 日本人の長寿, 肥満防止に役立つている」. 本 稿では，和食の特徵として取り上げられている「う ま味」が果たす役割や近年明らかになってきた栄 養・生理学的知見も併せて紹介する.

\section{うま味とは何か}

われわれは日々様々な食品を食事として摂取して いる。野菜, 肉, 魚介類や発酵食品である味増や㽜 油，チーズなどには，いずれも様々な遊離アミノ酸 が含まれている。食品中に含まれている成分につい ては食品成分表に詳細が示されている，食品成分表 はわが国の食生活を支える基本資料であり，特定給 食施設の栄養管理, 栄養指導, 疾病患者の食事設計 など，われわれの日常生活を始め学校給食における 栄養教育や研究分野, 食事摂取基準の策定, 食糧需 給表の作成, 国民健康・栄養調査の実施などの行政 
分野まで，非常に幅広い領域で活用される重要な情 報源である．2010 年の日本食品成分表改定により 食品成分表には「アミノ酸成分表」が加わり 337 品 目のアミノ酸の成分值が掲載されたことで食品中の アミノ酸組成を知ることが可能となつた。アミノ酸 は食品中のタンパク質を構成する成分であり，タン パク質の栄養価は主に構成アミノ酸の種類と量に よって決まるので，アミノ酸の総摂取量（すなわち タンパク質の摂取量）に加えてアミノ酸組成のバラ ンスが重要である。このアミノ酸組成表に示された 各種アミノ酸の数值にはタンパク質を構成するアミ ノ酸（結合アミノ酸）と遊離アミノ酸を合算したも のが示されている，栄養価が満たされていることに 加えて，食品の味を考えたときに遊離アミノ酸は非 常に大きな役割を果たしている，各種食品中の遊離 アミノ酸組成については, 個々の食品毎に論文を検 索するか日本栄養食量学会が公開している遊離アミ ノ酸データベース ${ }^{1)}$ のほかに，遊離グルタミン酸を 中心とした情報であれば NPO 法人うま味インフォ メーションセンターが Web で公開している. ${ }^{2)}$ アミ ノ酸が結合したタンパク質のほとんどは無味である が，食品中に存在する遊離アミノ酸にはそれぞれ特 有の味がある.グルタミン酸やアスパラギン酸は酸 性下では弱い酸味を持つが，中性付近ではうま味, プロリン，アラニン，グリシンなどは甘味，バリ ン，ロイシン，イソロイシンなど多くの必須アミノ 酸は苦味を持つアミノ酸である（Table 1)。これら の遊離アミノ酸は食品の味を構成する成分としての 役割を担っている。なかでもグルタミン酸は自然界 に最も多く存在するアミノ酸の 1 つであり，1980 年代以降のグルタミン酸に関する多くの研究によつ て，グルタミン酸はタンパク質の構成成分（結合ア ミノ酸)，食品の味の成分（遊離アミノ酸）である だけではなくタンパク質消化のためのシグナルを脳 に送ったり，腸管のエネルギー源あるいは腸管を保 護するグルタチオンの前駆体など様々な機能がある ことが報告されている. ${ }^{3)}$ グルタミン酸は食品中で はグルタミン酸イオンの状態で存在しているが，こ のグルタミン酸イオンの味が食品中で重要な役割を していることを発見し，その味を「うま味」と名付 けたのは日本の科学者 池田菊苗博士である. ${ }^{4,5)}$ 池 田は帝国大学を卒業後, 東京師範学校の教授, 帝国 大学の助教授などを務めたのち，明治 32 年（1899
Table 1. Taste of Free L-amino Acids

\begin{tabular}{c|c|c|c}
\hline \hline Sweet & Bitter & Sour & Umami \\
\hline Gly & Phe & Asp & Glu $\cdot \mathrm{Na}$ \\
Pro & Trp & Glu & Asp $\cdot \mathrm{Na}$ \\
Ala & Arg & Asn & \\
Thr & Ile & & \\
Pro & Val & & \\
Ser & Leu & & \\
Gln & Met & & \\
& His & & \\
\hline
\end{tabular}

年), 国費留学生としてドイツに留学し, 硝酸の生 成や触媒の研究で有名だったウィルヘルム オスト ワルドに師事している. オストワルドの下で最先端 の化学を学ぶことで日本の化学の振興に貢献するこ とが目的であったが，池田が大きく影響を受けたの はオストワルドの思想や生き方でもあった。池田は 留学中にドイッで初めて食べたトマト, アスパラガ ス，チーズ，肉など，いずれも当時日本では食べる ことができなかった食材の中に，四基本味（甘味, 酸味, 塩味, 苦味) 以外の味があり, しかも，その 味がトマト，アスパラガス，チーズ，肉のいずれに も共通している味であることに気付いた，明治 34 年（1901 年）に帰国した池田は昆布のだしの中に 自分がドイッで感じた味が鮮明に感じられることに 気付き，昆布の味の成分に関する研究を 1907 年に 開始している，当初はなかなか成果が得られず，途 中で実験を中断しているが，1908 年に「東洋学芸 雑誌」に掲載された，おいしく食べることが食べ物 の消化を促進するという医学博士 三宅 秀の論文 を読み，昆布のだしの成分を突き止め，その成分を 廉価な調味料とすることで国民の栄養状態の改善を 図ろうと研究を再開している。そして，同年グル夕 ミン酸イオンが昆布だしの味を構成する主要成分で あること，そしてグルタミン酸塩であるグルタミン 酸ナトリウムが最も明瞭な「うま味」を呈し，さら

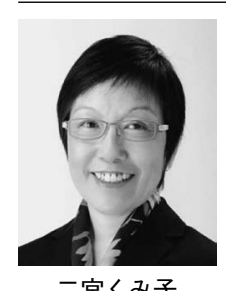

NPO 法人うま味インフォメーションセ ンター理事. 博士 (農学)。1985 年よ り, うま味研究の推進やうま味の普及 活動を積極的に行っている. 研究者と シェフの連携を通じて世界各地でうま 味のセミナー, シンポジウムを開催. また“うま味・だし”をテーマとした 食育活動においても, 幅広く活躍して いる。 
に調味料として最適であることを見い出している. 池田が成し遂げたうま味の発見とうま味調味料の発 明は，池田の本業である理論化学ではなく応用化学 の仕事である．池田がこのように応用化学に手を伸 ばしたのは，常日頃から「人類の発展に貢献する」 という大志を持っていたからであり，それはドイツ 留学時代に師事したオストワルドの影響によるとこ ろが大きく, 池田自身も「化学的研究によって開拓 できる範囲の広さや将来性を信じて研究を決心し た」と述べている.6)

\section{うま味と旨味}

ここで ‘うま味’と“旨み’（あるいは旨味）の 違いについて述べてみたい。日本語では“美味しい’ を表現する言葉として ‘旨い’ という言葉が使われ る。広辞苑では ‘旨夕’ とは美味しさの程度を表す 言葉であるとされている。 すなわち，“旨み’があ るかどうか，あるいは美味しいかどうかは個人に よって評価が異なるものであり絶対的な評価ではな い. 例えば，日本人にとつて馴染みのある納豆の味 は外国人には馴染みがなく，とても美味しいとは表 現し難い味であることが多い。このような場合，納 豆は日本人には“旨夕”があるが，外国人には“旨 み’がないということになる。したがって，“旨み’ という言葉には個人の好みが反映されている。一 方，“うま味’ はグルタミン酸塩の味である。うま 味は様々な食品の味を構成する成分の 1 つであり, 甘味, 酸味, 塩味, 苦味と並ぶ基本味の 1 つであ る.うま味以外の 4 つの基本味の味は誰もが容易に 想像することができる味であり，科学的にみればグ ルコースやスクロースの味は甘味，酢酸やクエン酸 の味は酸味, カフェインやカテキンの味は苦味, 塩 化ナトリウムの味は塩味である. 明確な味の概念が あり, 誰もが知つている 4 つの基本味に比べると, うま味は淡く曖昧な味であり食生活の中でうま味の みを味わったり意識することがあまりないこと，そ して日本人にとっては “旨み”すなわち美味しさと 混同されることが多く，本稿のテーマであるうま味 について正しく理解が浸透しているとは言い難い.

うま味の英語表記である umami は，基本味の 1 つ であるうま味を表す国際語として使われている。外 国人は umami の特徵を自分の言葉で表現しており 美味しさと混同されることなく正しい理解が得られ ている（Table 2)。7）うま味を理解した外国人シェ
Table 2. Expression of Umami by Culinary Professionals

Savory

Delicate and subtle

Mellow sensation

Earthy, musty and mushroom-like taste

Taste is like a big meaty and mouthful

It makes your mouth water

Mouth watering

Pleasant after taste with satisfaction

Lingering sensation

Subtle and ambiguous

Full tongue coating sensation

Fullness of taste that filled my mouth

It provide deep flavor and harmony and balance

Ninomiya K., 2015.7)

フ達は「うま味は人から教えてもらわないとわから ない繊細な味」あるいは「甘味，酸味，塩味よりも 持続性があり余韻を残す味」「唾液の分泌を促し口 腔内が潤つた感覚を起こす味」など，うま味の特徵 を具体的にわかり易く説明しており，このような表 現が日本でのうま味の説明にも役立っている。 10 年ほど前には，欧米人に昆布だしを味わわせても 「味がしない」とか「磯臭い，ヨード臭がする」な ぞのコメントしか返ってこなかったが，和食が普及 するとともにだしに対する理解も深まり正しく表現 することができるようになってきている．ワインの ソムリエたちが各種ワインの香りの表現方法を習得 していくのと同じように，多くのシェフたちが舌の 上に感じる微妙で繊細な感覚がうま味であることを 学んでいる，単にある食品や料理が美味しいか美味 しくないかを評価するだけではなく，体験を通して うま味はおいしさの一要素であることをきちんと理 解することが重要である. ${ }^{8)}$ うま味体験の具体的な 方法についてはうま味インフォメーションセンター のホームページでも紹介している. ${ }^{2}$

\section{だしとブイヨンの比較}

だしは和食に欠かすことができない，味増汁や吸 い物，蕎麦やうどんの汁，煮物，お浸しなど様々な 料理に使われている．われわれ日本人にとつてブイ ヨンは西洋料理のだしのようなものと考えられる が，だしとブイヨン中の遊離アミノ酸を比較してみ ると，その組成は大きく異なる（Fig. 1) .7,9) Figure 1 の左側の 2 つのグラフは昆布だしと一番だしに含 まれる遊離アミノ酸であるが，昆布だしには 2 つの 

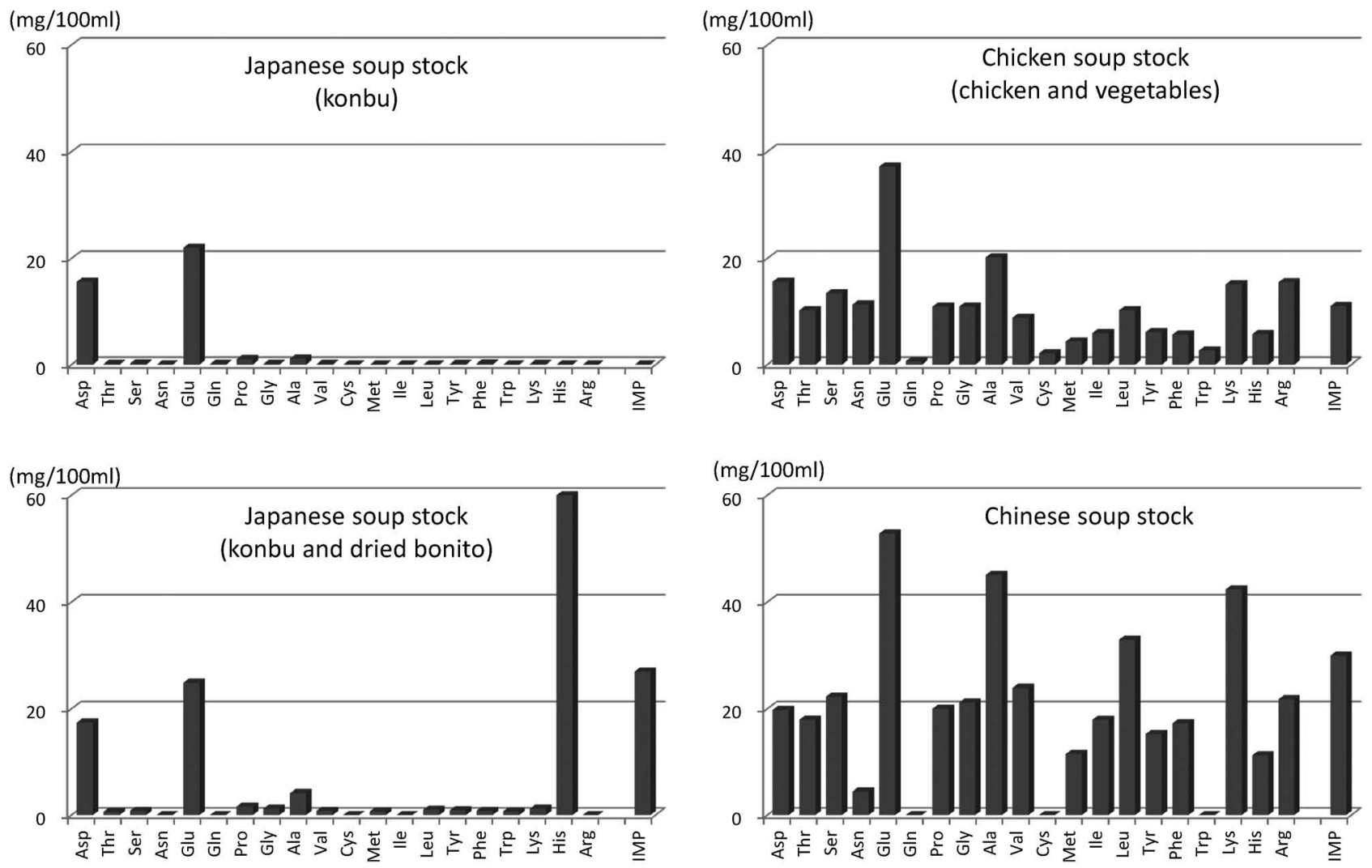

Fig. 1. Free Amino Acids and Inosinate in Japanese Soup Stocks, Chicken Soup Stock and Chinese Soup Stock Ninomiya K., 2015, () Umami Information Center 2014.

アミノ酸，すなわちグルタミン酸とアスパラギン酸 のみが含まれており，その他のアミノ酸はほとんど 含まれていない.グルタミン酸, アスパラギン酸と もに中性付近（昆布だしの $\mathrm{pH}$ は 6.7-6.8）でうま 味のあるアミノ酸である。一番だしは加熱した昆布 だしに鰹節を加えて調理したものであるが，この一 番だし中に含まれる主要な呈味成分は昆布だし由来 のグルタミン酸とアスパラギン酸，そして鰹節由来 のイノシン酸である。イノシン酸（5'-イノシン酸 塩）は，核酸系うま味物質であり，グルタミン酸と の相乗効果によってうま味を増強することが知られ ている. ${ }^{10,11)}$ グルタミン酸とイノシン酸による相乗 効果によって一番だしは昆布だしよりも強いうま味 を呈する，一番だし中に最も多く含まれているアミ ノ酸のヒスチジンは, カツオ, イワシ, サバなど一 般的に「青魚」あるいは「背の青い魚」と言われて いる魚で海洋表層近くを群れで回遊している魚に多 く含まれるのが特徵である. ${ }^{12)}$ ヒスチジンは非常に 弱い酸味をだしに与えている. 一方, 西洋料理のブ イヨンや中国料理の湯（たん）と呼ばれるものは,
うま味物質のみに着眼すれば，肉や野菜に含まれて いたグルタミン酸, そして, 肉から抽出されたイノ シン酸による相乗効果によってうま味が増強されて いるが，それ以外の成分も多く含まれており，素材 の野菜や肉などから様々なアミノ酸が抽出されてお り，うま味だけではなく，これらのアミノ酸の呈味 によって複雑な味が構成されていると言える。この ように和食, 西洋料理, 中国料理のだしを比較して みると, 和食はうま味を中心に構成されている料理 と言える．池田は和食の文化の中で育ち，その中心 的な成分を昆布だしから発見したことがきっかけで, 1909 年に全く新たな調味料であるグルタミン酸ナ トリウムを発明している，そのきっかけは「佳良に して廉価なる調味料を造りだし，粗食を美味ならし むることが国民の栄養不良を矯救せしむる」という 考えである. 食事として摂取したものをきちんと栄 養素として消化・吸収していくためには，おいしく 食べることが重要であるという発想である。ほとん ぞ同じ時期にスイスのジュリウス マギーは製粉技 術を学び，製粉工場を取り仕切っていた。19 世紀 
末のヨーロッパは工業化の進展が目覚ましく，その ことが社会構造に変化をもたらしており, 女性の社 会進出が始まっていた。マギーの工場でも近隣の主 婦たちが働くようになった結果，女性が家事に時間 をかけることができなくなり, 栄養不足が大きな社 会問題となりスイス公共福祉協会の議題に挙がるほ どまでになっていた、マギーは工場検査官であり医 師であったシューラー師とともに食品の研究を重 ね，ひよこ豆のタンパク加水分解物（遊離アミノ酸 の混合物）をべースとした粉末状のスープを 1885 年に開発，その後 1908 年にはキューブ状のブイヨ ンを開発した. ${ }^{13)}$ 全く異なる国で，それぞれの食文 化を反映させ，しかも，池田もマギーも栄養改善を 目的に簡便な調味料を作り出しているのは興味深い 事実である.ヨーロッパではマギーによるブイヨン キューブの発明だけでない。 ドイツの化学者 ユス トス フォン リービッヒ男爵は牛肉エキスを煮詰め てペースト状にしたものを作っている，これも，牛 肉エキスに含まれているアミノ酸の混合物である. その後，牛肉エキスの製造は工業化されイギリスに リービッヒ肉エキス会社 (The Liebig Extract of Meat Company）が設立されたのは 1865 年であ る. ${ }^{14)}$ 池田はうま味の発見とうま味調味料の発明に ついて,「グルタミン酸塩の味について」と題して

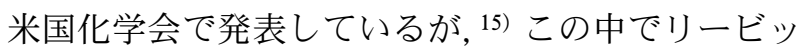
ヒの肉エキスにもうま味があると述べている。 ま た，ビール製造に使用された酵母のエキスを濃縮し たペーストであるマーマイトが商品化されたのは 1902 年である. ${ }^{16)} 19$ 世紀の後半から 20 世紀初頭に かけて，ヨーロッパでは彼らの食生活にあったかた ちで，そして彼らが慣れ親しんできた味，すなわち グルタミン酸のうま味を含むアミノ酸の混合物が様 々な形態で商品化されていった。一方，日本では池 田がグルタミン酸ナトリウム製造法の特許を得てい るが，当時は小麦のタンパク質を加水分解し，その 中からグルタミン酸のみを抽出しそのナトリウム塩 を調味料としていた．それぞれが親しんだ食文化の 違いによって単独のアミノ酸であるグルタミン酸を 主成分とする調味料を作り出した日本人に対し, ヨーロッパでは様々な素材からアミノ酸混合物が商 品化されていったことは, 食文化の背景と工業や化 学の発展の関連が見てとれる興味深い事実である.

\section{うま味が主役の伝統調味料や食材}

ヒトは長い歴史の中で，食物を安定的に確保し， さらにそれを保存する技術や火を使って調理をする 技術を獲得してきた。 得られた作物を乾燥すること で保存が可能に，また，肉や魚を塩漬けにしたり発 酵させたりすることも，美味しく食べる工夫のみで はなく保存食としても優れている。このようにして 作られてきた伝統調味料や発酵食品などは世界各地 にみられる (Fig. 2)。東洋と西洋の境目と言われ るトルコから東の国々では魚介類や大豆や穀物など を発酵させて作られた調味料が多い。これらはいず れも発酵の過程で素材の持つタンパク質がアミノ酸 に分解され，その結果グルタミン酸が豊富に含まれ る調味料ができあがっている，和食に欠かせない味 増や眢油を始め，東南アジアの国々で使われている 各種魚奨もグルタミン酸を多く含む調味料である (Table 3).17)一方，トルコから西の国々ではトマ 卜を用いたペースト，肉や乳製品から作られた発酵 食品である生八ムやチーズなどが伝統的に作られて きた。 トマトはコロンブスの新大陸発見以降にヨー ロッパに渡り普及していった食材であるが，それら が各国で親しまれているソースやペーストのベース として使われている。トマトにはグルタミン酸が豊 富に含まれており，昆布と同様にグルタミン酸とア スパラギン酸が全遊離アミノ酸の中の $90 \%$ 以上を 占めている (Table 4).18) 乾燥, 発酵, 塩漬けなど 本来は美味しく食べるためや食品の保存のために行 われた手法であるが，科学的に見るといずれもグル タミン酸を保存, 濃縮, あるいは増やす方法でも あったと言える。

\section{うま味と満足感}

母乳中の遊離アミノ酸組成を見るとグルタミン酸 が非常に多く含まれている（Fig. 3) . ${ }^{19)}$ 母乳中に含 まれている遊離グルタミン酸の生理学的役割につい ては現在，米国で研究が進められているが，1つの 可能性としてはグルタミン酸によるうま味は満足感 （Satiety）に関与している可能性があることが米国 モネル研究所による乳児を対象とした研究で示され いる. ${ }^{20)}$ さらにイギリスの Sussex 大学の研究チー ムによる成人を対象とした研究でもうま味は満足感 に関与していることが報告されている. ${ }^{21)}$ 米国モネ ル化学感覚研究センターによる乳児を対象とした研 究では, タンパク質加水分解物を基本とした粉ミル 


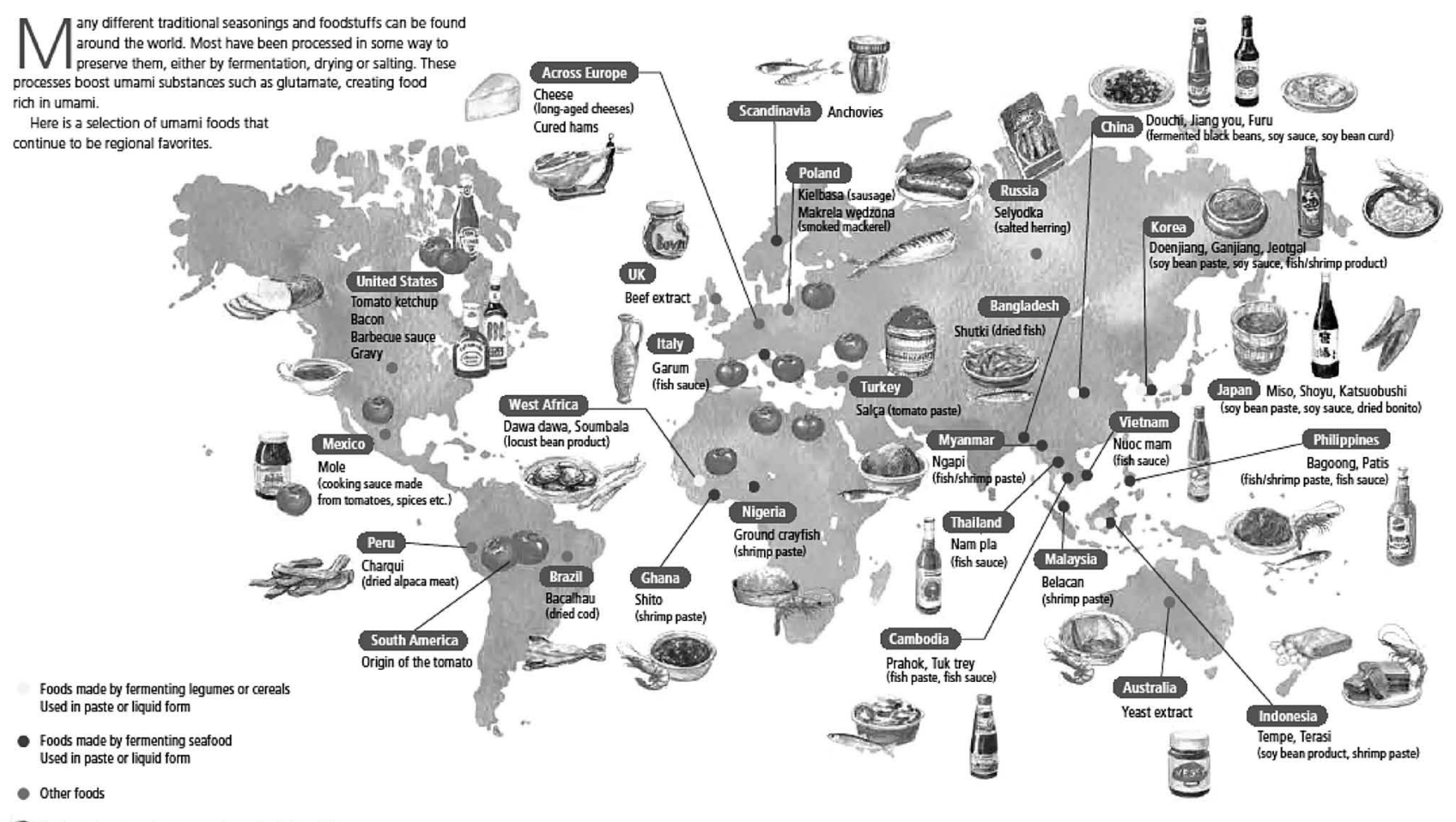

Fig. 2. Traditional Foods around the World and Umami (C) Umami Information Center.

Table 3. Free Glutamate Contents in Fermented Seasonings $(\mathrm{mg} / 100 \mathrm{~g})$

\begin{tabular}{lllr}
\hline \hline Fish sauce & Nam-pla & Thailand & 950 \\
& Nuoc mam & Vietnam & 1370 \\
& Patis & Philippine & 988 \\
& Basakang & Indonesia & 465 \\
& Budu & Malaysia & 620 \\
& Ishiru & Japan & 1383 \\
Fermented beans & Soy sauce & China & 926 \\
& Soy sauce & Japan & 782 \\
& Soy sauce & Korea & 1264 \\
& Miso (Sendai)* & Japan & 690 \\
& Miso (Shiro) ${ }^{*}$ & Japan & 270 \\
\hline
\end{tabular}

Yoshida Y., 1998;17) * data from Umami Information Center.

クを摂取している乳児と通常の粉ミルクを摂取して いる乳児の体重増加を比較したところ，通常の粉ミ ルクを摂取している乳児のほうが正常な体重増加を 上回る体重増加率を示していることが報告されてい る. 一方，タンパク加水分解物をベースとした粉ミ ルク摂取群では，正常な体重増加を示している，通 常の粉ミルクとタンパク加水分解物を使った粉ミル クで大きく異なるのは遊離アミノ酸含量である。通 常の粉ミルクの遊離グルタミン酸は $10 \mu \mathrm{mol} / 100$
Table 4. Free Amino Acids in Tomato $(\mathrm{mg} / 100 \mathrm{~g}$ )

\begin{tabular}{lrc}
\hline \hline & Locular & Pericarp \\
\hline Asp & 39 & 30 \\
Ser & 49 & 94 \\
Glu & 143 & 77 \\
Gly & 2 & 1 \\
Ala & 5 & 5 \\
Val & 1 & 2 \\
Met & 2 & 2 \\
Ile & 2 & 3 \\
Leu & 4 & 3 \\
Tyr & 4 & 4 \\
Phe & 13 & 14 \\
Lys & 9 & 9 \\
His & 5 & 6 \\
Arg & 5 & 5 \\
\hline Total & 283 & 255 \\
\hline
\end{tabular}

Ninomiya K., 1998. ${ }^{18)}$

$\mathrm{mL}$ であるのに対し，タンパク加水分解物をベース とした粉ミルクでは約 75 倍近くのグルタミン酸 (タンパク加水分解物ではグルタミン酸とグルタミ ンの合算值）が含まれている. 通常の粉ミルクにグ ルタミン酸ナトリウムを添加した場合にはミルクの 摂取量がタンパク加水分解物ベースのミルク摂取群 


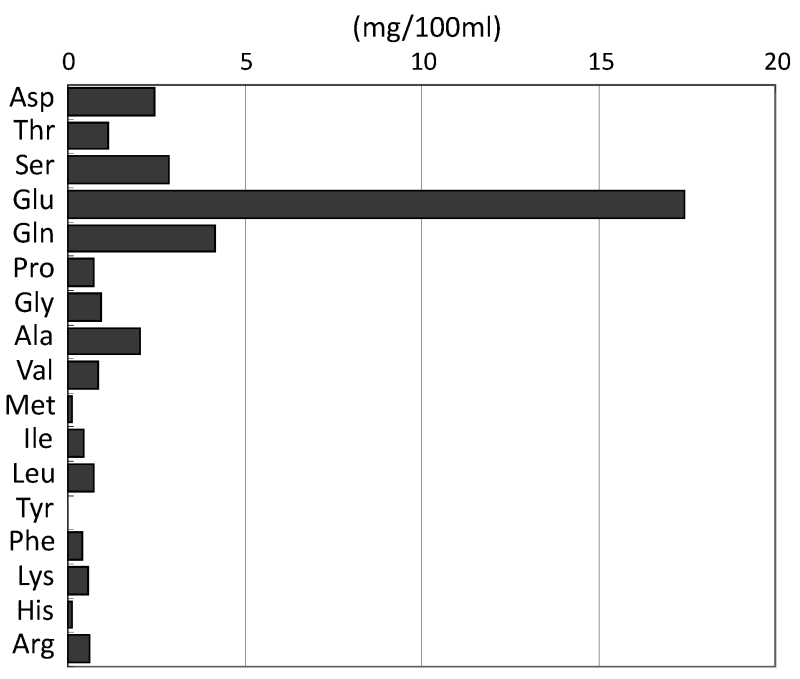

Fig. 3. Free Amino Acids in Human Breast Milk from Healthy Woman after 1 Month from the First Lactation ( $n$ $=40$ )

Agostoni C. et al., 2000. ${ }^{19}$

と同程度の摂取量となる。このことからグルタミン 酸は食欲をコントロールし満足感に関与している可 能性があることが示されている，乳児期の過体重や 肥満は, 成人後の肥満やそれに伴う様々な疾患の原 因となることから WHO では生後 6 力月までの母 乳摂取を推奨している。 また，成人を対象とした研 究では，被験者は試験前日深夜より絶食，試験当日 は全員が同じ朝食を摂取し，昼食摂取 45 分前にう ま味（グルタミン酸ナトリウムとイノシン酸ナトリ ウム）を添加したスープと添加していないスープを 摂取した群について，その後のパスタの喫食量を調 ベた。うま味添加スープ摂取群ではパス夕喫食前の 空腹感がうま味無添加スープ摂取群よりも強いにも かかわらず，パス夕摂取量は，うま味添加スープ摂 取群のほうが少ない量で満足感を得ている（満足す るまで喫食した時点の喫食量が少ない)。さらに, 事前に摂取するスープは高タンパク質であるほう が，より効果があることを報告している，スープと パス夕摂取による総摂取カロリーはうま味添加スー プ群のほうが低くなっているにもかかわらず満足感 が得られていることがこの研究で注目すべき点であ る. 先進国では過度な肥満が社会問題ともなってお り，おいしく食べつつ過食にならないというメッ セージは Times 紙の Web 版に掲載された 'Eat Umami, Eat Less’ という記事がきっかけとなり, フランス語, イタリア語, オランダ語, ポルトガル
語, アラビア語，インドネシア語，中国語，韓国 語，そして日本語も含め 70 件近くの関連記事が Web で発信された。おいしくかつ健康な食につい ての関心の高さが窺われる事象の 1 つと言える，近 年, 消化管に味覚受容体が存在することがわかって きており，胃にも代謝型グルタミン酸受容体 I 型が 存在することが明らかになり, ${ }^{22)}$ 食事から摂取する グルタミン酸の生理学的な役割の解明が進んでい る. 胃のグルタミン酸受容体は食物中の遊離グル夕 ミン酸を受容すると，その情報は迷走神経を介して 胃から脳に伝えられ, 脳から各組織にシグナルが送 られることで胃液や膵液などの分泌が促進され食物 の消化を助けている. ${ }^{23-25)}$ 胃から脳へのシグナル伝 達の役割をしたグルタミン酸のほぼ $95 \%$ は小腸で エネルギー源として使われている. ${ }^{26)}$ われわれの生 命活動に不可欠であるタンパク質の摂取を体に伝え るグルタミン酸によるシグナルと満足感，満腹感や 食欲に関するより詳細な研究の進展が期待されてい る.

\section{うま味の価値再考}

和食の基本形とされるのが一汁三菜，すなわちご 飯に汁物, おかず三種（主菜 1 品, 副菜 2 品）で構 成される献立である。この献立の形態は時代ととも に変化しつつあるが，だしを中心とした汁物の摂取 の習慣は日本独特のものであり, 今後も継承してい きたいものである. 日々の汁物摂取がボディーマス 指数（BMI）の増加，メタボリックシンドローム とは負の相関関係にあることがイタリア，フラン ス, ポルトガルなどの研究チームによる疫学調査で 報告されている. ${ }^{27-29)}$ フランスの調査結果を見ると BMI が 27 以上の人は，時々スープを飲むか全く飲 まない人たちであるのに対し，ほとんど毎日スープ を摄取する人は BMI が 23 以下である。 日本で行 われた疫学調査では，24-75 歳の男性約 100 名を対 象としたもので汁物（ほとんどの場合が味増汁）を 摂取する頻度が多いほど肥満係数（腹囲/ヒップ比） が小さいこと，30）また，男性 103 名，女性 401 名 (20-76 歳) を対象とした調査では味増汁摂取頻度 及び食物繊維の摂取が肥満のリスクとは負の相関関 係があることが示されている. ${ }^{31,32)}$ 汁物にはだしが 不可欠であり，だしにはうま味が豊富に含まれてい る. 池田博士によるうま味発見から 100 年以上が経 過し，漸くおいしく食べることが食物の消化に関与 
していること，そして満足感や健康にも関与してい ることが科学的に実証されてきている．日常の食生 活におけるうま味の存在とその価值を再認識し後世 に受け継いでいきたいものである.

利益相反＼cjkstart開示すべき利益相反はない.

\section{REFERENCES}

1) Japan Society of Nutrition and Food Science: $\langle$ http: // www.jsnfs.or.jp / database_aminoacid.html $\rangle$, cited 5 May, 2016.

2) Non-Profit Organization Umami Information Center: 〈http://www.umamiinfo.jp $\rangle$, cited 17 May, 2016.

3) Young V. R., Ajami A. M., J. Nutr., 130, 892S-900S (2000).

4) Ikeda K., Japan. Patent 14805 (1908).

5) Ikeda K., Tokyo Chem. Soc., 30, 820-836 (1908) .

6) National Diet Library, The 17th Kaleidoscope of Books: 〈http://www.ndl.go.jp/kaleido/entry/17/index.html $\rangle$, cited 2 August, 2016.

7) Ninomiya K., Flavour, 4, 13 (2015).

8) Ninomiya K., Katsuta Y., "Umami: The Fifth Taste, Basic information and ways to learn more," Japan Publications Trading, Co., Ltd., Tokyo, 2014, pp. 136-151.

9) Ninomiya K., Kitamura S., Saiga-Egusa A., Ozawa S., Hirose Y., Kagemori T., Moriki A., Tanaka T., Nishimura T., Journal of Home Economics of Japan, 61, 765-773 (2010) .

10) Kuninaka A., J. Agric. Chem. Soc. Jpn., 34, 751-757 (1960).

11) Yamaguchi S., J. Food Sci., 32, 473-478 (1967).

12) Fuke S., Konosu S., Physiol. Behav., 49, 863868 (1991).

13) Heer J., "Nestlé 125 Years, 1866-1991," Nestlé, Vevey, 1991, pp. 1-525.

14) Funaki R., Hissu Aminosan Kenkyu, 178, 5962 (2007).

15) Ikeda K., Proceediugs of the 8th International Congress of Applied Chemistry, Vol. 38, 1912, p. 147.

16) Hartley P., "The Marmite Cookbook," Absolute Press, Bath, 2003.

17) Yoshida Y., Food Rev. Int., 14, 213-246 (1998).

18) Ninomiya K., Food Rev. Int., 14, 177-211 (1998).

19) Agostoni C., Carratù B., Boniglia C., Riva E., Sanzini E., J. Am. Coll. Nutr., 19, 434-438 (2000).

20) Mennella J. A., Ventura A. K., Beauchamp G. K., Pediatrics, 127, 110-118 (2011).

21) Masic U., Yeomans M. R., Physiol. Behav., 116-117, 23-29 (2013).

22) Kondoh T., Mallick H. N., Torii K., Biosci. Microflora, 28, 109-118 (2009) .

23) Uneyama H., Niijima A., San Gabriel A., Torii K., Am. J. Physiol. Gastrointest. Liver Physiol., 291, G1163-G1170 (2006).

24) Zolotarev V., Khropycheve R., Uneyama H., Torii K., Ann. NY Acad. Sci., 1170, 87-90 (2009) .

25) Tsurugizawa T., Uematsu A., Nakamura E., Hasumura M., Hirota M., Kondoh T., Uneyama H., Torii K., Gastroenterology, 137, 262273 (2009).

26) Akiba Y., Watanabe C., Mizumori M., Kaunitz J. D., Am. J. Physiol. Gastrointest. Liver Physiol., 297, G781-G791 (2009).

27) Reeds P. J., Burrin D. G., Stoll B., Jahoor F., J. Nutr., 130, 978S-982S (2000) .

28) Giacosa A., Filibert R., Med. Doctor, 8, 40-45 (1997).

29) Bertrais S., Galan P., Renault N., Zarebska M., Preziosi P., J. Hum. Nutr. Diet, 14, 121128 (2001).

30) Moreira P., Padrão P., Eat. Behav., 7, 220228 (2006).

31) Kuroda M., Ohta M., Okufuji T., Takigami C., Eguchi M., Hayabuchi H., Ikeda M., $J$. Am. Diet. Assoc., 111, 137-142 (2011).

32) Kuroda M., Ohta M., Okufuji T., Takigami C., Eguchi M., Hayabuchi H., Ikeda M., Appetite, 54, 538-543 (2010). 